\section{Decisions about the European computer industry}

In deciding whether to approve more funds for Compagnie Internationale pour l'Informatique (CII), the French member of the European computer grouping Unidata, the French government is having to weigh up the long term prospects of, for example, an alliance with an American company. Professor A. S. Douglas, Professor of Computational Methods at the London School of Economics and Past President of the British Computer Society examines the underlying issues.

European cooperation, as has been recently demonstrated in Washington, is often difficult to achicve. Nowhere had this proved more true than in computing, and the latest report of the problems of CII is only one further manifestation of the phenomenon.

\section{Case for indigenous industry}

There are some very obvious reasons why an indigenous computer industry is desirable in any count ry. Industry, commerce and government itself are all coming increasingly to depend on the efficiency and speed of computers in handling clerical tasks, plant control and planning studies. The industry is already the third largest, in terms of turnover, after oil and aircraft. At least one company in the industry, IBM, is highly profitable. Thus each government, nervous of the effect which foreign control of this key resource might have on its own efficiency and that of local industry, seeks to protect itself and its 'charges' as best it can, and local interests seek to participate in the profits which should flow from a new and growing industry.

Since the computer industry has its roots, in the main, in the United States, the general fear of external interference may be made more or less pointed by the political climate existing between any country and the United States. The more concern over political implications, the more urgeney is there to avoid undue dependence on technology from the United States; the stronger the local interests in the industry, the more concern there is to build up local industry under some form of protective umbrella which will hamper United States activity locally.

The arguments which have led many governments, including those of Britain, France, West Germany and Japan, to subsidise and protect their local interests against the supposed 'threat', are, of course, valid concerning neighbouring governments which may be thought to hold an important card in the industry. Thus cooperation is apt to be approached in a spirit of suspicion. Only if the external threat to a group is deemed strong enough, or if there is an obvious pay-off for all, is it likely that the suspicions will be overcome and a real measure of cooperation take place.

\section{Arguments for cooperation}

Setting aside the strength (or otherwise) of this 'threat' from the United States-on which opinions will clearly differ-and the rather more general sentimental arguments in favour of cooperation within Europe, the primary arguments for cooperation are commercial. Computers, even minicomputers, are relatively complicated machines, both to build and to maintain. Good design makes for reliability and case of maintenance but such design only results from the incorporation of experience. Experience is gained from use, and is the more quickly learned the more machines are sold and used. Thus quantity production leads not only to reduced unit costs, as with all products, but also to a more sharply convergent 'leaning enrve' towirds the lower unit costs themselves.

There is, then, a double prize for achieving quantity production, and this can only be done in a large market. Europe is a fast-growing computer market and will, no doubt, in time become similar in size to that in the United States. A truly European marketing strategy, if pursued without political hampering, ought to be sound commercially. A sensible selection of points of attack on the dominance of the United States ought to sueced, whether or not governmental support is available, provided the companies concerned are at least as well managed as their competitors. All companies are, however, somewhat vulnerable in the course of their early developments and when a mijor investment in say, a new range of computers is being made, so perhaps there is a case for support. What is really needed is access to the whole European market on a basis of parity in each country and the price for this seems to be 'multinationalisation' of the firms concerned.

Because I believe that there is sound commercial sense in aiming to achieve a freer market situation, I would suppose that governments will press forward with collaborationthough obviously on the best terms each feels it can get for its own protegées. Probably, therefore, a solution will be found to the problems of CII and cooperation with Siemens and Philins will continuc.

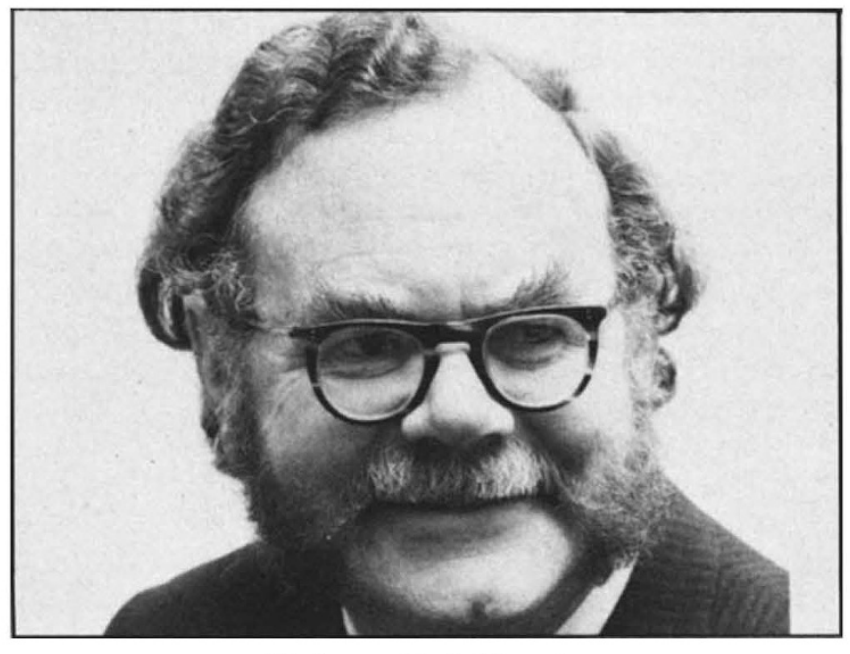

Professor A. S. Douglas

\section{Britain}

Meanwhile the British position recuires careful consideration to see what is likely to be in the interest of British industry as a whole. Clearly ICL is an important part of the industry and its interests must be considered. But there are important sections in peripherals, minicomputer terminals, software and bureau operation, where government action can have equally important influences and where money is 10 be made both at home and abroad by good husbandry. So far, the Department of Trade and Industry has tended to pay very little attention to these areas and has concentrated its policy around the support of ICL alone. Recently there have been welcome signs of change, and it is to be hoped that a broader view will be taken in the future. 